\title{
Severe iron anemia deficiency caused by hookworm: Case report and literature review
}

\author{
Julio C. Giraldo-Forero ${ }^{1,2 *}$, Laura A. Muñoz-Niño ${ }^{3}$ and Karen V. Coronado-Castiblanco ${ }^{3}$ \\ ${ }^{1}$ Parasitology and Tropical Microbiology Research Group, Biology Program, INCCA University Colombia; ${ }^{2}$ School of Medicine, Military University \\ Nueva Granada; ${ }^{3}$ Infectious Diseases Research Seedbed, School of Medicine, Military University Nueva Granada. Bogotá, Colombia
}

\begin{abstract}
Background: Hookworms, cosmopolitan geohelmintiasis by Ancylostoma duodenale, and Necator americanus infect more than 1 billion people. Objective: The aim of this study was to present a clinical case of severe iron anemia and literature review report. Materials and methods: This was a descriptive study with a review of the clinical history and literature. Results: A 19-year-old patient, who was referred to the Hospital Militar Central, presented with paraclinical signs showing severe anemia; abdominal pain for 3 weeks, with emesis and fetid liquid stools, with mucus, without blood, asthenia, adynamia, and feeling light-headed; generalized asymptomatic physical examination with pallor, tachycardia, and with the presence of low intensity systolic murmur in the aortic focus. He was diagnosed with severe microcytic hypochromic heterogeneous anemia with a probable ferropenic origin. He got a transfusion of red blood cells and was managed with o-meprazole, ferrous sulfate, and albendazole. Conclusion: In Colombia, the prevalence of hookworms is $13 \%$, iron deficiency, $4.9 \%$, and iron deficiency anemia in school children, $0.6 \%$.
\end{abstract}

Key words: Hookworms. Iron deficiency anemia. Ancylostoma duodenale. Necator americanus.

\section{Introduction}

Hookworms are a cosmopolitan parasitosis. It is typical of tropical countries, especially underdeveloped ones in which their highest clinical manifestation is tropical anemia ${ }^{1,2}$ presenting with gastrointestinal hemorrhage due to ulceration of the mucous before the angle of Treitz, which could manifest as hematemesis, hematochezia, or melena ${ }^{3}$. The diagnosis is confirmed with an endoscopy and a stool parasitological exam to identify the possible causing agent ${ }^{2,4}$.

Ancylostomides, nematode parasites localized in the duodenal region, are the main agents associated with bleeding ulcers given their hematophagic activity, from which the genus and species that impact human health are Ancylostoma duodenale and Necator americanus, the latter being the most prevalent in Latin American tropical countries ${ }^{2,5}$.

Routine exams to diagnose these entities are direct and formol-ether concentration stool parasitological tests which are techniques that allow for direct diagnosis but do not quantify or determine parasitemia levels. The Kato-Katz method was used, to establish the intensity of the infection, since it has an advantage over the former two, though still limited since it does not allows for identifying the genus or species of the etiological agent ${ }^{6,7}$, making it necessary to complement it
Correspondence:

*Julio César Giraldo-Forero

E-mail: jcesargiraldo @ gmail.com
Available online: 17-10-2019

Rev Med Hosp Gen Mex. 2019;82(4):215-220

www.hospitalgeneral.mx

0185-1063/@ 2018 Sociedad Médica del Hospital General de México. Published by Permanyer México SA de CV. This is an open access article under the CC BY-NC-ND license (http://creativecommons.org/licenses/by-nc-nd/4.0/). 
with stool cultures, including agar, to induce egg hatching, and to generate larva stages which facilitate the differentiation between both genera and species ${ }^{8}$.

To get infected by these parasites, direct contact with soils contaminated with filariform larvae stages is required; they enter through the skin and move through the circulatory system to the heart, lungs, and the duodenum region in the small intestine, where they develop into adults that fix themselves to the mucous with their teeth for $A$. duodenale, or cutting plates for $N$. americanus, which are differential morphological characteristics of the genus and the species $^{9}$. Other infection routes include the oral ingestion of larvae stages present in water or vegetables or vertical due to the invasion of the filariform larvae to the mammary glands and infection of the baby through breast milk ${ }^{3,8,10}$. The most severe pathology caused by both entities is the mechanical and expollable action due to the generation of bleeding ulcers due to hematophagic activity, leading to iron deficiency anemia, which requires transfusion treatment along with a high iron and protein diet ${ }^{5,8,11-14}$.

\section{Case report}

This was a 19-year old patient from Vichada, without any important clinical history, who was referred to the Hospital Militar Central due to paraclinical results that showed severe anemia. When he was admitted, he presented with a 3-week consistent evolution of colicky abdominal pain, localized in the right hypochondrium, associated with emetic episodes of food content and abundant liquid, fetid, mucus, bloodless depositions, asthenia, adynamia, and feeling fainting sensation.

During the physical examination, the patient was asymptomatic and showed generalized pallor, tachycardia, and a low-intensity systolic murmur in the aortic focus. Paraclinical exams were then taken; the total abdominal echography was within normal limits, and the hemogram showed: hemoglobin: $5 \mathrm{~g} / \mathrm{dl}$; hematocrit: $21.3 \%$; mean corpuscular volume: $56.10 \mathrm{fl}$; mean corpuscular hemoglobin: $13.2 \mathrm{pg}$; red cell distribution width: $23.3 \%$; ferritin: $2.29 \mathrm{ng} / \mathrm{ml}$; iron: $11.0 \mu \mathrm{g} / \mathrm{dl}$; transferrin: $296 \mathrm{mg} / \mathrm{dl}$; folic acid: $13.7 \mathrm{ng} / \mathrm{ml}$, and Vitamin B12: $420 \mathrm{pg} / \mathrm{ml}$ which corresponds to severe microcytic, hypochromic heterogeneous anemia with a probable iron deficiency origin. His hepatic and renal profiles, electrolytes, coagulation times, urine test, and gram coloration were within normal limits.

Direct diagnostic exams such as thick blood test and $\lg G$ and $\lg M$ antibodies were negative, but the stool ova and parasite test were positive for occult blood. In addition, HIV and venereal disease research laboratory were negative. He was transfused with three units of red cells, and a post-transfusion hemogram showed: hemoglobin: $8.6 \mathrm{~g} / \mathrm{dl}$; hematocrit: $31.5 \%$; mean corpuscular volume: $62.9 \mathrm{fl}$; mean corpuscular hemoglobin: $17.2 \mathrm{pg}$, and red cell distribution width: $28.8 \%$. He was treated with oral omeprazole, $20 \mathrm{mg}$, and ferrous sulfate, $300 \mathrm{mg}$, every $8 \mathrm{~h}$.

\section{Stool parasitological evaluation \\ Direct stool parasitological test}

We observed hookworm egg stages, with a characteristic thin, hyaline membrane and the presence of blastomeres when measuring the objective at $\times 40$ and with the calibrated ocular micrometer they had an average length of $75.7 \mu \mathrm{m}$ and a diameter of $46 \mu \mathrm{m}$ (Fig. 1). In the direct stool parasitological test, we observed Charcot-Leyden crystals and mucus, and it was complemented with the modified Ritchie-Frick method, corroborating the presence of hookworms ${ }^{4,7}$.

\section{Determining parasitemia levels}

We performed the Kato-Katz technique to count eggs, which is the preferred method according to the World Health Organization (WHO), reporting 7392 eggs/g of feces for hookworms ${ }^{8}$.

\section{Stool culture technique}

We inoculated approximately $1 \mathrm{~g}$ of feces in nutrient agar plates. At the same time, we added the physiological saline solution to a portion of the collected deposition and both samples were incubated in a moist chamber at $23^{\circ} \mathrm{C}$. After 6 days, we observed migration channels made by the larvae stages in the culture medium, and in the stool microscopic exam we observed the filariform stages (Fig. 2) ${ }^{12}$

Assessing the paraclinical test results, we discarded malaria infection, an immunocompromised state, and syphilis, which associated the hypochromic, and microcytic iron deficiency anemia due to the presence of hookworms and defining the disease as severe tropical anemia requiring a transfusion. In addition, we gave him anti-parasitic medication with albendazole, hydration, antiemetic, gastric protector, and ferrous sulfate.

In the parasitological evaluation of the stool, we observed a coinfection with Ascaris lumbricoides and Trichuris trichiura and concomitant to these geohelminthiases; there were Blastocystis spp. cysts. 


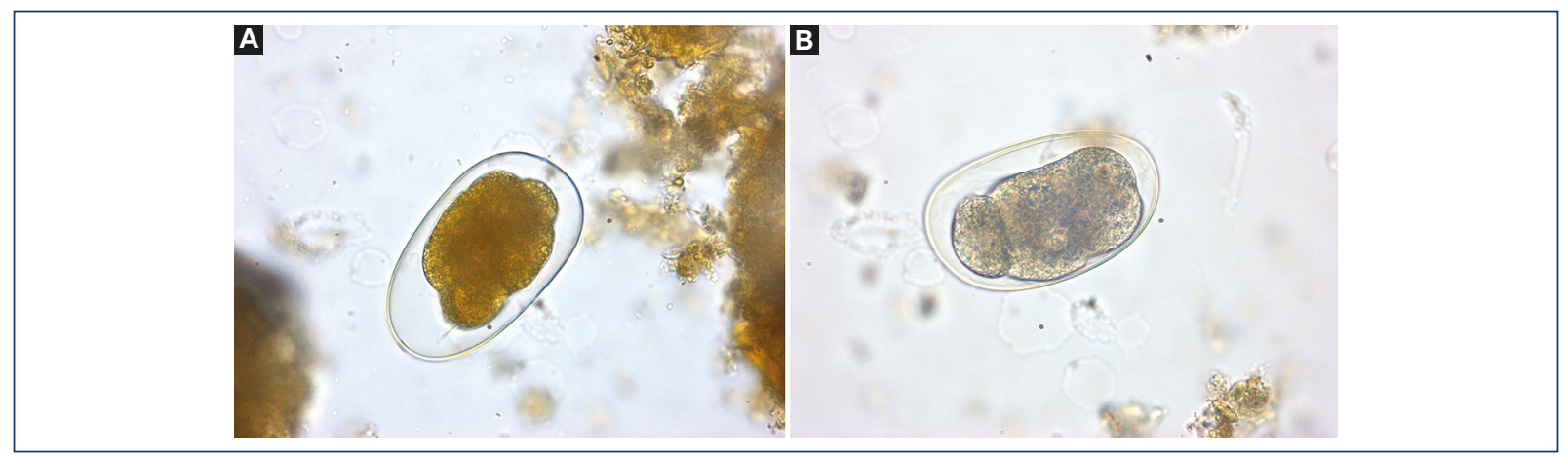

Figure 1. A, B: embryonated hookworm egg mounted with Lugol, $\times 45$. We observe the thin hyaline membrane and the blastomeres.

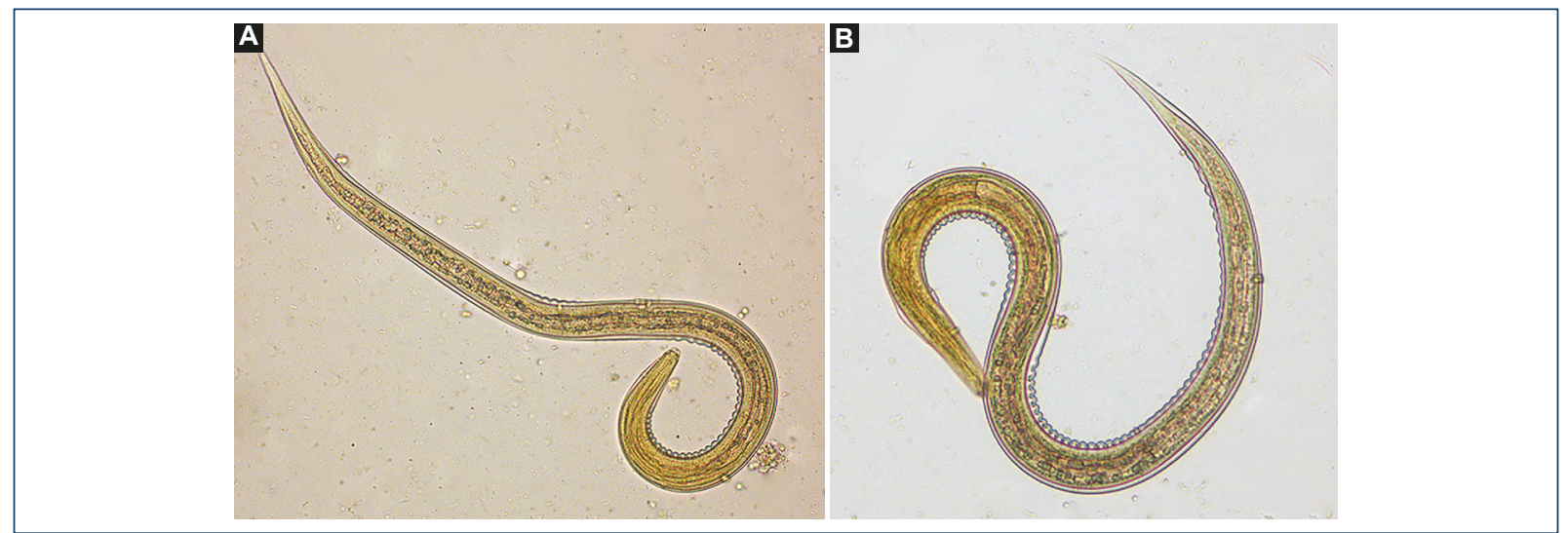

Figure 2. A, B: hookworm filariform larva obtained from stool culture, observed with Lugol's solution, $\times 45$.

We estimate that one of the important causes for blood loss, be it open or occult, is associated with parasite infections among which we can highlight those produced by hookworms. It is important to clarify that direct stool parasitological tests are not always required as part of routine diagnostic tests, and when performed, they only involve direct diagnosis techniques, without including those that allow for recounting or identifying the etiological agent.

The count of hookworm eggs with an intense parasitemia level allows for the explanation of the severe anemia state shown by the patient, with a hemoglobin value of $5 \mathrm{~g} / \mathrm{dl}$, and the malnutrition state, worsened by the coinfection with $A$. lumbricoides and $T$. trichiura (Fig. 3). The infection level for the former was elevated with $6480 \mathrm{~h} / \mathrm{g}$ of feces, and mild for the latter because it was $<2000 \mathrm{~h} / \mathrm{g}$. It is important to note that the national survey reports prevalence values for these two geohelminths of $23.3 \%$ and $50.7 \%$, respectively.

\section{Discussion}

A. duodenale and $N$. americanus are endemic in tropical and subtropical regions with elevated prevalence's. It is estimated that between 740 million and 1 billion people are infected with hookworms in the world ${ }^{1,5}$, and the parasitosis is considered a neglected tropical disease that is relevant in public health ${ }^{4}$. This constitutes one of the main causes of iron deficiency anemia, especially in vulnerable populations such as children and women of childbearing age or pregnant. Hookworm disease is one of the geohelminthiases with the greatest impact in rural areas and urban zones where basic conditions are not satisfied. According to the report for the last national survey, reference values in Colombia are around $13 \%$ with mild infection levels ${ }^{3,6}$. Adult parasites are localized in the small intestine mucosa (duodenum and jejunum), initially causing small hemorrhages, which could persist for various years, decreasing iron, and consequently, generating an iron 


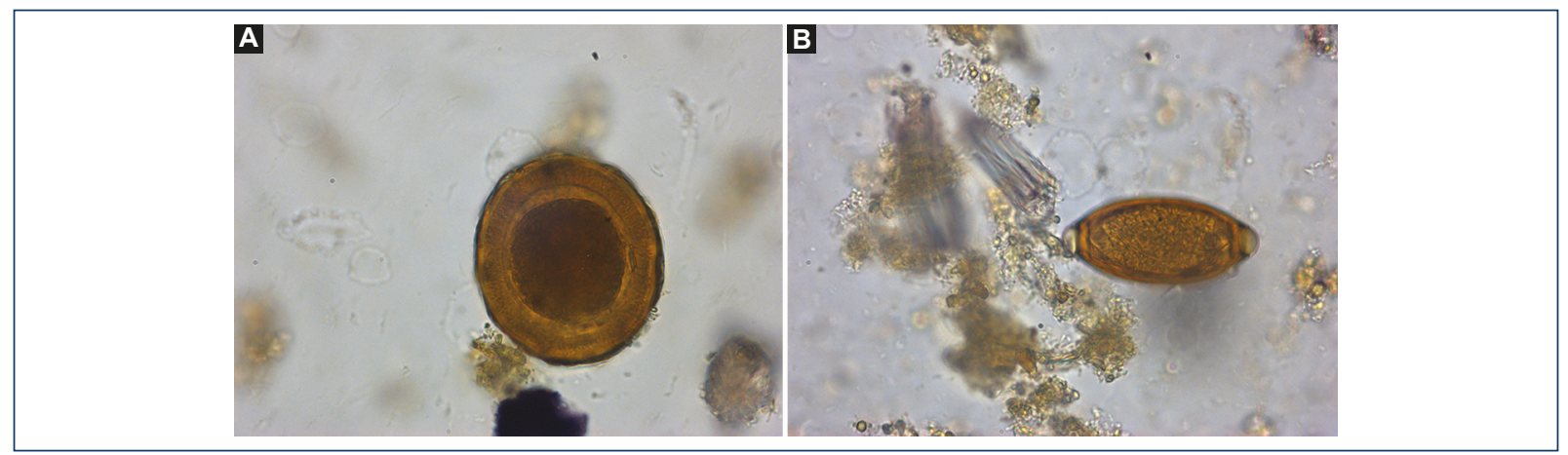

Figure 3. A: fertile Ascaris lumbricoides egg. The thick cover and mamelones can be observed; B: Trichuris trichiura egg.

deficiency in patients. This allowed the WHO to consider the classification and diagnosis of hookworm disease in patients with scarce or no anemia and/or iron deficiency anemia ${ }^{15}$.

Iron deficiency, also known as tropical anemia, follows blood loss caused by hemorrhages from the lesions caused by the erosion and the ulcers product of the mechanical action of the cutting plates or teeth characteristic of each species and the biochemical action of the secretion of hydrolytic enzymes, anticoagulants, factor Xa and VIla inhibitors caused by adult stages. The main infection route for $A$. duodenale and $N$. americanus is through the skin, generating dermatitis as a result of either toxic and chemical components or toxic allergic actions due to the migration of cutaneous larvae to the circulatory system, causing the pulmonary cycle, Löeffler's syndrome, pulmonary edema, alveolar lysis, eosinophilic infiltration of the parenchyma, allergy by immunoglobulin E, fever, bronchitis, and pneumonia.

Other infection routes include the oral ingestion of filariform larvae present in the water or vegetables, and vertical transmammary in breastfed infant population $^{3,10}$, in which case the pulmonary cycle is not performed, with direct settling in the intestines. We estimate that each adult parasite in the host can ingest around $0.2 \mathrm{ml} / \mathrm{blood} /$ day. The severity of the disease depends on the parasitemia level, the nutritional and immunological status of the host. $N$. americanus and A. duodenale females oviposit between 8000 and $12,000 \mathrm{~h} /$ day on the $1^{\text {st }}$ day and between 5000 and 25,000 eggs/day on the $2^{\text {nd }}$ day $^{2,8}$, which are not in infectious stages per $\mathrm{se}^{3}$. In severely infected patients, extraintestinal localizations have been observed, including the stomach, proximal ileum, and colon ${ }^{5}$.

To diagnose, it is vital to take into account the origin of the patient. To identify the parasitosis a simple stool parasitological testing is performed which could be complemented with Kato-Katz concentration and count techniques. Stool culture methods like Harada-Mori in agar allow for the differentiation of the genus and species. Indirect serodiagnosis techniques, such as the indirect hemagglutination test, complement fixation test, diffusion in agarose gel, ELISA, and others do not have much applicability ${ }^{8}$. Molecular characterization by polymerase chain reaction in real-time using specific primers for the ITS2 sequence of $A$. duodenale such as Ad125f, and for the ITS2 of $N$. americanus such as NA58F and Na158R is useful in phylogenetic studies ${ }^{5,16}$. We estimate that infections with a Kato-Katz count between 3300 and 16,400 eggs/g of feces are classified on the scale as medium to intense and that it would correspond to a population of 50-99 adult females ${ }^{12}$. When the population of parasites is estimated to be over 500 , the patient has a severe infection ${ }^{17}$.

For the treatment of hookworm disease, the WHO recommends $100 \mathrm{mg}$ of mebendazole every $12 \mathrm{~h}$ for 5 days, which has less collateral effects than other anti-parasite drugs, though in children younger than 2 years it should be used with caution. This drug has a recovery rate between $76 \%$ and $95 \%$ and an egg count reduction between $83.7 \%$ and $99.9 \%^{3} ; 10 \mathrm{mg} / \mathrm{kg}$ of thiabendazole for 3 days ${ }^{18}$; one dose of albendazole $400 \mathrm{mg}$ or $10 \mathrm{ml}$ oral suspension in adults and children older than 2 years; $250 \mathrm{mg} / 5 \mathrm{ml}$ pyrantel pamoate suspension that puts a neuromuscular block on sensitive helminths, immobilizing the parasites and provoking their expulsion without excitation or stimulating their migration $^{8}$.

Patients with hookworm disease could present with multiple intestinal parasites along with other geohelminths that take advantage of the nutrients of the 
organism of the host, with A. lumbricoides being one of the most frequent, estimating that an adult could consume $160 \mathrm{mg}$ of protein per day. Another etiological agent that could be present simultaneously is T. trichiura, which increases malnutrition and whose mechanical action on the mucosa causes inflammation of the internal wall of the intestine and increases the speed of intestinal transit, and decreases the time for proteins to be used adequately. In addition, the ingestion of blood of $A$. duodenale or N. americanus could be between 0.04 and $0.20 \mathrm{ml} /$ day by adult parasites, which finally ends in an iron deficiency anemia that entails a lack of energy and decrease in appetite, nutritional deficit and a decrease in school productivity due to malnutrition ${ }^{19}$.

Another geohelminth that may be concomitant with hookworms is Strongyloides stercolaris, which in immunosuppression situations might be seen as opportunistic in nature, multiplying quickly due to the change from non-infectious larvae to invasive filariforms, which causes hyperinfection and massive dissemination that provokes multiorgan dysfunction with a death rate of up to $70 \%$. These conditions are commonly seen in patients treated with corticoids, neoplastic carriers, transplanted patients, or those infected with HTLV-1. We cannot discount that hookworm disease may show similar behavior, which makes it important to treat and check for the negativization of the fecal samples between 4 and 6 weeks after it is finished ${ }^{17}$.

Developed countries have recently reported an increase in the incidence of hookworm disease cases associated with immigrant population. For this reason, the WHO recommends performing screening in patients with suspicion of iron deficiency anemia, even those who are asymptomatic, and whose origin is an endemic region for these parasitoses ${ }^{11,20}$.

\section{Conclusion}

In Colombia, the prevalence of hookworms is $13 \%$, iron deficiency $4.9 \%$, and iron deficiency anemia in school children $0.6 \%$.

\section{Acknowledgments}

The authors would like to thank the Hospital Militar Central, the School of Medicine of the Universidad Militar Nueva Granada, Orlando Torres-Fernández and Gerardo Santamaría-Romero from the Cell Morphology Group of the INS.

\section{Conflicts of interest}

The authors declare that they have no conflicts of interests.

\section{Funding}

The authors did not receive any financing for the development of this research. The patient was hospitalized in the Hospital Militar Central.

\section{Ethical disclosures}

Protection of human and animal subjects. The authors declare that no experiments were performed on humans or animals for this study.

Confidentiality of data. The authors declare that they have followed the protocols of their work center on the publication of patient data.

Right to privacy and informed consent. The authors have obtained the written informed consent of the patients or subjects mentioned in the article. The corresponding author is in possession of this document.

\section{References}

1. Roca C, Balanzó X, Sauca G, Fernández J, Boixeda R, Ballester M. Uncinariasis importada por inmigrantes africanos: estudio de 285 casos. Med Clin Barc. 2003;121:139-41. Available from: http://www.elsevier.es/ es-revista-medicina-clinica-2-articulo-uncinariasis-importada-por-inmigrantes-africanos-13049803.

2. García D, Jáquez J, González J, Maldonado H. Hemorragia de intestino medio causada por uncinariasis y diagnosticada por cápsula endoscópica. Caso clínico. Rev Gastroenterol Méx. 2013;78:196-200. Available from: http://www.revistagastroenterologiamexico.org/es/hemorragia-intestino-medio-causada-por/articulo/S0375090613000505.

3. Valdivieso $P$, Cetraro D, Angulo D. Hemorragia digestiva en neonato con uncinarias, hospital nacional san bartolomé. Rep Caso. Soc Gastroenterol Perú. 2017;37:82-6. Available from: http://www.revistagastroperu.com/ index.php/rgp/article/view/84.

4. Cabezas M, Salas J. Casos de Microbiología Clínica. Unidad de Medicina Tropical APES-Hospital Poniente Almería; 2014. p. 1-3. Available from: http://www.f-soria.es/admfsoria/casos/img/caso_596.pdf.

5. Nair G, Cazorla E, Choque H, White A, Cabada M. Infección masiva por Ancylostoma duodenale como causa de hemorragia intestinal y anemia severa. Soc Gastroenterol Perú. 2016;36:90-2. Available from: http://www. scielo.org.pe/scielo.php?pid=S1022-51292016000100014\&script=sci_arttext.

6. Minsalud. Encuesta Nacional de Parasitismo Intestinal en Población Escolar Colombia, 2012-2014. Universidad de Antioquia, Instituto Nacional de Salud; 2015. Available from: https://www.minsalud.gov.co/sites/rid/Lists/BibliotecaDigital/RIDE/VS/PP/ET/encuesta-nacional-de-parasitismo-2012-2014.pdf.

7. Giraldo J, Guatibonza A. Comparación de sensibilidad y especificidad de dos técnicas de diagnóstico directo: kato-katz-saf y ritchie-frick (formol-gasolina) en examen coproparasitológico para la identificación de estadios infectivos de geohelmintos en población infantil en edad preescolar y escolar. Rev Med. 2017;25:22-41. Available from: https://www. revistas.unimilitar.edu.co/index.php/rmed/article/view/3088/2620.

8. Tamayo L, Yaniquez R, Padilla L. Anemia severa causada por Necator americanus: Reporte de un caso. Cuadernos. 2008;53:52-5. Available from: http://www.biblioteca.fment.umsa.bo/docs/tc/v530109.pdf.

9. Ángel R, Raad J, Pérez J, Marín J, Hoyos J. Uncinariasis: hallazgo incidental durante CPRE. Assoc Colomb Gastroenterol. 2005;20:72-5. Available from: http://www.scielo.org.co/scielo.php?script=sci_arttext\&pi$d=S 0120-99572005000100011$.

10. Kaminsky R. Primer informe de Ancylostoma duodenale en honduras. Descripción clínica y parasitológica. Med Hond. 2000;68:142-8. Available from: http://www.bvs.hn/RMH/pdf/2000/pdf/Vol68-4-2000-6.pdf. 
11. Aizpuro E, García E, Nuño F, Sánchez V. Varón con anemia ferropénica severa por uncinariasis. Med Clin. 2002;119:518-9. Available from: http:// www.scielo.isciii.es/scielo.php?script=sci_arttext\&pi$\mathrm{d}=\mathrm{S} 0212-71992006000900014$.

12. Peredo A, Carpio G, Torrico M. Relación entre la presencia de anemia y la infección por uncinarias, en estudiantes del colegio "Ayopaya", Puerto Villarroel-Cochabamba. Rev Méd Cient Luz Vida. 2012;3:21-6. Available from: http://www.redalyc.org/pdf/3250/325028226005.pdf.

13. Dala $F$, Cleaves $F$, Velásquez $O$, Matamoros M, Zavala A. Sangrado Digestivo Masivo por Uncinariasis, Presentación de dos Casos Clínicos. Publicación; 1991. Available from: http://www.cidbimena.desastres.hn/ RHP/pdf/1991/pdf/Vol14-1-1991-6.pdf.

14. Mosquera G, Correa N, Concha A. Sangrado oscuro y anemia crónica severa: discusión sobre dos causas gastrointestinales subvaloradas en Colombia. Reporte de caso. Univ Méd. 2014:55:229-34. Available from: http://www.revistas.javeriana.edu.co/index.php/vnimedica/article/viewFile/16303/13091.

15. García C, Cano J, Ortega E, Martín P. Varón brasileño de 19años con anemia ferropénica grave. Enferm Infec Microbiol Clín. 2015;33:211-2. Available from: http://www.elsevier.es/es-revista-enfermedades-infecciosas-microbiologia-clinica-28-articulo-varon-brasileno-19anos-con-anemia-S0213005X14002201.
16. Jonker $\mathrm{F}$, Calis J, Phiri K, Brienen EA, Khoffi H, Brabin BJ, et al. Real-time PCR demonstrates Ancylostoma duodenale is a key factor in the etiology of severe anemia and iron deficiency in Malawian pre-school children. PLoS Negl Trop Dis. 2012;6:1555-60.

17. Rodríguez A, Pozo E, Fernández R, Amo J, Nozal T. Uncinariasis como causa de anemia ferropénica en población penitenciaria. Rev Esp Sanid Penit. 2013;15:63-5. Available from: http://www.scielo.isciii.es/scielo.php?script=sci_arttext\&pid=S1575-06202013000200004\&Ing=es\&nrm=iso.

18. Pérez $M$, Rodríguez $O$, Barceló $B$, Sanchen $A$. Larva migrans cutánea: reporte de cuatro casos. AMC. 2014;18;218-25. Available from: http:// www.scielo.sld.cu/scielo.php?script=sci_arttext \&pi$d=S 1025-02552014000200008 \& \operatorname{lng}=e s \& n r m=i s 0$.

19. Kuon L. Repercusión sobre la productividad estudiantil de las helmintiasis intestinales. Rev Méd. 2012;18:183-6. Available from: https://www. juntadebeneficencia.org.ec/revista/vol18no4/2441-repercusion-sobre-la-productividad-estudiantil-de-las-helmintiasis-intestinales.

20. Failoc V, Molina C, Rodríguez A. Uncinariasis: una enfermedad importada en España. Microbiologia. 2015;33:700-2. Available from: http://www. elsevier.es/es-revista-enfermedades-infecciosas-microbiologia-clinica-28-articulo-uncinariasis-una-enfermedad-importada-espana-S0213005X15001482 